\title{
PEDRO PAULO ABREU FUNARI: A WORLD ARCHAEOLOGIST
}

Carlos Fabião ${ }^{1}$

Pedro Paulo Abreu Funari is a relevant social scientist, mainly in the specific domains of Archaeology and Ancient History but also with major contributions in several other areas in a broader domain that one can define as theoretical issues in History and Archaeology. The recognition of his scientific and academic work by his peers is clearly expressed in the more than five thousand quotations recorded in Google Scholar (https://scholar.google.com.br/citations?user=gQgnsTgAAAAJ\&hl=pt-BR). This useful tool for academic evaluation also records twenty co-authors of his papers and books from different geographical academic environments, from Europe to the United States of America, South America, with an obvious major expression in Brazil.

Looking at the list of Funari's articles and books one may see that he is also a multilingual author: Portuguese, Spanish, English, French are some of the idioms used. This multilingual skills can also be seen as a cultural statement against dominant fashion trends in research. The world is diverse and that diversity should be shown in scientific publication.

This general overview of Google Scholar presents an author with an ample perspective, with no specific academic affiliation, but concerned with diversity, someone that is aware of the major changing in the Archaeological Science of his own time and with a strong commitment of what it was called the Archaeology of the Future by the seminal statement of the World Archaeological Congress: "In fact this is the archaeology of the future. The discipline of archaeology is no longer the exclusive province of white European upper-class men, and there is no going back to a pre-WAC era of exclusionary, hierarchical and scientized knowledge that marginalizes the multivocal archaeology from the peripheries. The question of "who controls the past?" is no longer a conundrum because it must be generally conceded that there are many pasts and they will be known differently from many views." (http://worldarch.org/history-wac/)

\footnotetext{
${ }^{1}$ Associate Professor, University of Lisboa, Lisboa, Portugal. E-mail: cfabaiao@campus.ul.pt
} 
According to his own experience and personal ethical commitment, Funari became not just a partner of this generational major change but an active agent in this process, with regular contribution both in WAC's Conferences and journal. He was also responsible for the wide diffusion of these perspectives in the Lusophone world, that's why I choose the epithet of World Archaeologist to Pedro Paulo Abreu Funari.

But let's take a look at the beginning of Funari's scientific activity, using his own autobiographical text published in the collective volume concerning the panorama of Brazilian's Classical Archaeology (Grillo; Funari; Carvalho, 2013).

Funari explains in his testimony the first inclination towards philosophical and theoretical issues and also a particular aim on studying dictatorship regimes, difficult to develop under a totalitarian regime. But at the end, he went to Ancient History, chiefly Roman Economic History. I would say that "there's no love as the first love", and that could explain how Funari lately approaches the theoretical issues and also the archaeology of repression and its expression in Ibero-America.

In the domain of Roman Economic History, Funari chooses to work with some peculiar sources: on one hand, amphorae, the typical Roman containers to transport foodstuffs from one region to others, that means use archaeological artefacts to approach the interprovincial connectivity within Roman Empire; but also the epigraphic issues related to the amphorae, stamps, the more relevant elements concerning its fabric centres, and dipinti, those cursive inscriptions, painted with freehand, concerning commercial issues. It's important to stress that those research areas are very complexes and peculiar, so Funari has to go to Europe to acquire the adequate training with senior specialists, to deal with those very different historical sources.

In one of his first published scientific articles on amphorae studies, Funari presents the guidelines of his research combining Classical Literature, reading and interpreting dipinti, and ceramic studies in a coherent eclectic approach (Funari, 1986) he also expresses his gratitude to some European leading researchers on the subject, from Italy, Spain, and France, an expressive demonstration of his openness to different research schools, and it's important to notice that there are not yet references to British scholars in this paper.

Latter, Funari moves to Great-Britain to study the evidence of Baetican olive-oil exports to that northern Roman Province in a research line that becomes one of his major contributions to the Roman economic studies, 
expressed namely in the book written with Cesar Carreras Monfort on the subject (Carreras Monfort; Funari, 1998). Funari arrives in Britain and works in the British academic environment, but with a previous nonBritish training and that explains his own independent approach. He also chooses the most relevant scientific centres to develop his already established skills: Southampton for ceramic/amphorae studies (http://archaeologydataservice.ac.uk/archives/view/amphora_ahrb_2005/), and the CEIPAC group in Barcelona for amphorae epigraphy (http://ceipac.ub.edu/).

Funari returns several times to the olive oil distribution an consumption with other relevant contributions, such as Funari, 2008, just to mention one of them, expressing his concerns on using a solid theoretical approach to the military and non-military consumption patterns of olive oil in Britannia's Roman Province.

More recently, Funari joint the research line on the archaeology of violence and repression in Ibero-America full filing his pristine aim of studying the dictatorships, now in a free democratic context, something that was not possible in his early years of a student. Once again Funari demonstrates his commitment to the WAC spirit of an Archaeology ethical and political concerned, not the supposed aseptic attitude of the years pre WAC, in other words, being an agent of that Archaeology major scientific change.

Other recent Funari texts deal with the nowadays very popular subject of Public Archaeology, actually, an old concern of Funari, going back to the Fifth WAC Conference in Washington and from then on a regular subject in his papers. Another research line is the so-called historical archaeology, once again a recurrent subject on Funari's scientific work and one of the major research fields within the World Archaeological Congress, reflecting the opening of Archaeology to other different non-European research geographies.

This very short account of the deeds of Pedro Paulo Abreu Funari should also stress his major contribution to teaching and training of students from different academic levels, from graduation to post Ph.D. level. In these essential domains, Funari has also a solid contribution to the development of Brazilian Archaeology as one can see in the frequent mentions in many contributions published in the book on the pathways of Brazilian Classical Archaeology (Grillo; Funari; Carvalho, 2013). I would say that major influence can also be seen in some of his companions on Classical Texts made with pedagogic concerns, which were used by students, and also in many short articles published in 
newspapers or book reviews, always an important reference to any student on Archaeology and Ancient World.

Pedro Paulo Abreu Funari is definitely a World Archaeologist with a huge solid scientific academic work, always done with a strict theoretical framework, and also a solid ethical attitude that is and should be a model for students and academic peers.

\section{References}

Carreras Monfort, C.; Funari, P. P. A. (1998): Britannia y el Mediterráneo: Estudios Sobre el Abastecimiento de Aceite Bético y Africano en Britannia.. Barcelona: Publicacions de la Universitat de Barcelona. (Col.lecció Instrumenta, 5).

Funari, P. P. A. (1986) Em torno da ânfora. A terminologia latina dos vasos recipientes. Revista de Guimarães, 96, p. 219-227.

Funari, P. P. A. (2008) La contribution d'une approche postprocessual pour la comprehension de la consommation d'huile d'olive en Bretagne romaine. Stodia Historica / Historia Antigua, 26, p. 271-302.

Grillo, José Geraldo Costa; Funari, Pedro Paulo A.; Carvalho, Aline Vieira de (Eds) (2013) Os caminhos da arqueologia clássica no Brasil: depoimentos. São Paulo: Annablume (Coleção História e Arqueologia em Movimento). 